\title{
Investigating internal and external factors influencing profitability of banking industry
}

\author{
Hadi Noori $^{\mathrm{a}^{*}}$ and Mehdi Taghavi ${ }^{\mathrm{b}}$
}

${ }^{a}$ M.Sc. of Economic, Market Risk analyzer of Mellat bank, Iran

${ }^{b}$ Professor and Faculty member, Department of Economic, University of Allame Tabatabaei, Tehran, Iran

\begin{tabular}{|c|c|}
\hline A R T I C L E I N F O & ABSTRACT \\
\hline $\begin{array}{l}\text { Article history: } \\
\text { Received March 25, } 2012 \\
\text { Received in revised format } \\
\text { 25 September } 2012 \\
\text { Accepted } 8 \text { October } 2012 \\
\text { Available online } \\
\text { October } 112012 \\
\text { Keywords: } \\
\text { Return on assets } \\
\text { Banking profitability } \\
\text { Time series analysis }\end{array}$ & $\begin{array}{l}\text { This paper presents an empirical investigation to learn the impact of some internal and external } \\
\text { factors on profitability in banking system. The proposed model of this paper introduces three } \\
\text { econometrics methods to study the behavior of internal, external and a combination of both } \\
\text { factors on return on assets. The proposed study of this paper uses Vector Auto- Regressive } \\
\text { (VAR) and Vector Error Correction Model (VECM) to provide estimation of the proposed } \\
\text { model and we use historical data over the period of 1989-2010. The results of the first model } \\
\text { for internal factors, we consider some independent variables including ratio of total revenue on } \\
\text { total assets (TR) and ratio of total equities on total assets (TE). The second model considers the } \\
\text { effects of external variables on ROA such as growth domestic product (GDP) and market share } \\
\text { (MS) and the last model includes a combination of both internal and external factors. The } \\
\text { results indicates that there is a positive and meaningful relationship between logarithm of } \\
\text { growth domestic product and return on equities, which means as we expect one unit increase in } \\
\text { LGDP, there is an increase of } 0.012 \text { on ROA. In addition, when the market share increase by } \\
\text { one percent, there will be an increase } 0.025 \% \text { increase on ROA and an increase of one percent } \\
\text { in the ratio of TR will yield to an increase of one percent in ROA. }\end{array}$ \\
\hline
\end{tabular}

\section{Introduction}

During the past few years, there have been tremendous efforts on measuring the impacts of various factors on profitability of banking systems. Khodaei Valahzaghard et al. (2012) used some regression anaylsis on some banking systems and reported that there was no relationship between the inflation rate, employment rate, unemployment rate, the dollar, the euro, with import growth of credit risk in the banking system in Iran. They concluded that the credit risk in the banking system in Iran under the effect of variables was not mentioned. In addition, positive and significant relationship between stock index and credit risk in the banking system in Iran had increased.

\footnotetext{
* Corresponding author. Tel: +98-912-5146114

E-mail addresses: h.nori@bankmellat.ir (H. Noori) 
Khodaei Valahzaghard and Salehi (2012) studied corporate governance and ownership impacts on earning quality in Iranian private banks. They implemented the information of 12 private banks over the period of 2005-2010 using regression analysis based on panel data. Among various factors, the effect of big five shareholder were considered to be significant and positive on earning quality. In addition, the impact of one variable regression test revealed that institutional ownership had positive influence on earning quality. However, the effects of other variables including percentage of ownership concentration, the size of board of directors, reliance on debt, logarithm of sum of assets, return of assets, logarithm of operating cash flow on earning quality were not meaningful. They explained that institutional ownership plays an important impact on earning quality simply because institutions normally have the access on professionals to control management.

Corporate governance is described as the system in which companies are directed and controlled and it includes regulatory and market mechanisms (Ball \& Shivakumar, 2008). Bozec and Laurin (2008) investigated that the largest publicly traded companies throughout the world had concentrated ownership especially the ones in countries like Canada where voting rights are concentrated in the hands of large shareholders, mostly wealthy families. Such concentrated ownership structures generates specific agency problems, such as large shareholders expropriating wealth from minority shareholders. They made an assessment on the effect of separation on different performance metrics while controlling for situations when the large shareholder had the chance to expropriate and the incentive to expropriate.

Cain et al. (2009) did a survey on the implementation of income-decreasing special items to manage earnings. They explained that low-quality special items could violate the concept of a transitory item, as they were related to future operating cash flows, while high-quality special items could not. They reported that low-quality special items could forecast accounting restatements, while high-quality special items do not.

Baboucek and Jancar (2005), based on some monthly data for the Czech Banking Sector (1993 to 2005), investigated the proportion of delayed loans to the whole of facilities as an indicator of the quality of loans. Based on the results of the fitted model, the strong relationship between quality of loans and some economic variables for the immediate reaction was confirmed. They reported that unemployment, consumer price index (CPI), inflation and credit risk shocks increase the real exchange rate. They also explained that the stress-test considering the impact of such shocks to the economy of the Czech banking sector fragility measure could be used to further analyzing the results..

\section{The proposed study}

The proposed study of this paper uses econometrics method to study the behaviour of profitability, which has the following form,

$R O A=F(T a, T E, T C, T R, L G D P, L L I Q, L L R, M S)$,

where ROA is the return of asset, TE is capability of equity and it is calculated as a ratio of total equities on total assets, TL is total liquidity and it is calculated as a ratio of total payable cash on total assets, TR is calculated as a ratio of total revenue on total assets, LGDP is logarithm of growth domestic product, LLIQ is logarithm of existing liquidity in economy, LLR is logarithm of official registered rate and finally, MS is market share. The proposed study of this paper uses Vector AutoRegressive (VAR) and Vector Error Correction Model (VECM) to provide estimation of the proposed model and we use historical data over the period of 1989-2010. The first step for the proposed model of this paper is to underestand whether the data are stationnary or not. Table 1 shows Dikki-Fuller ratios for all variables and their first order differences. 
Table 1

Dikki-Fuller (DF) ratios for independent variables

\begin{tabular}{lllllll}
\hline Variable & Critical value & ADF & Difference & Critical value & ADF & Level of Significance \\
\hline ROA & -3.79 & 0.71 & dROA & -3.81 & -3.9 & $1 \%$ \\
TR & -3.79 & -0.67 & dTR & -3.81 & -5.03 & $1 \%$ \\
TL & -3.79 & -2.87 & dTL & -3.81 & -4.06 & $1 \%$ \\
TC & -3.79 & -1.13 & dTC & -3.81 & -4.98 & $1 \%$ \\
TE & -3.79 & -1.54 & dTE & -2.65 & -2.69 & $10 \%$ \\
MS & -3.79 & -3.09 & dMS & -3.81 & -5.32 & $1 \%$ \\
LLR & -3.79 & -2.42 & dLLR & -3.81 & -4.32 & $1 \%$ \\
LGDP & -3.83 & 0.4 & dLGDP & -3.03 & -3.23 & $5 \%$ \\
LLIQ & -3.79 & -0.67 & dLLIQ & -2.65 & -2.66 & $10 \%$ \\
\hline
\end{tabular}

As we can observe, when we take the first difference all adjusted DF (ADF) values become greather than critical values and the results of first difference, $\left[I_{1}\right]$ are stationnary.

\section{The results}

\subsection{The effects of internal factors}

We first process the the effects of internal factors using the following model,

$R O A=F(T C, T R, T L, T E)$,

Table 2 summarizes the necessary tests associated with model (2)

\section{Table 2}

The results of Schwarz Information Criterion (SBC), Akaike Information Criterion (AIK), Logarithm of lag and Lag

\begin{tabular}{llll}
\hline LOGL & SBC & AIK & Lag \\
\hline 398.4296 & -34.60043 & -36.34296 & 0 \\
428.0763 & -36.06723 & -38.30763 & 1 \\
444.1203 & $-36.17377^{*}$ & $-38.91203^{*}$ & 2 \\
451.7237 & -35.43624 & -38.67237 & 3 \\
\hline
\end{tabular}

Impulse-Response Functions measure the effects of different inpulse of resuduals $\left(\varepsilon_{t}\right)$ on independent variables in different time horizons and the results of this function are shown in Fig. 1.
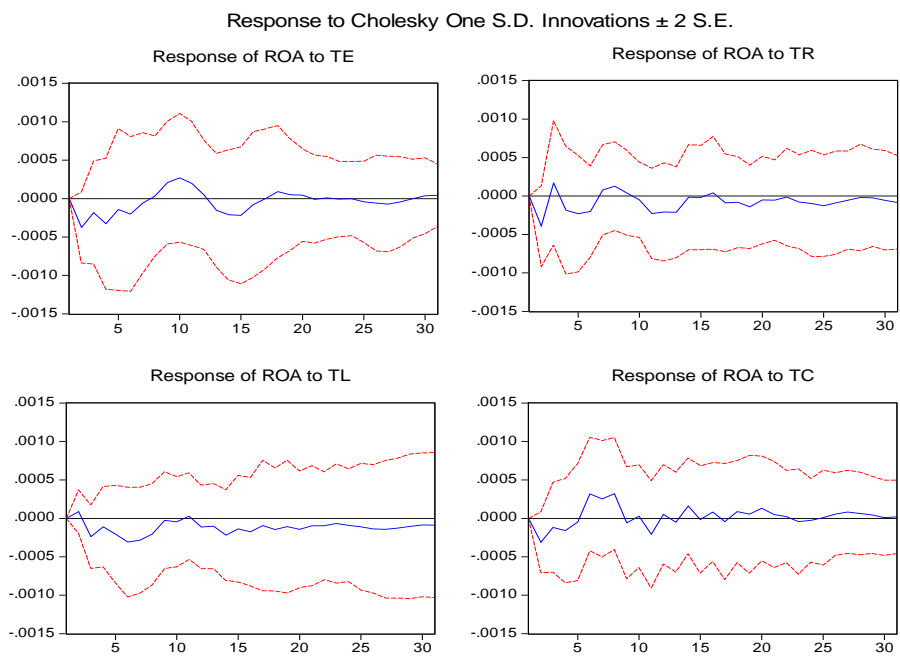

Fig. 1. Response to Cholesky One S.D. Innovations 
2726

Johansen and Juselius cointegration analysis (Johansen, 1988-91; Johansen \& Juselius, 1994) is another useful method to determine co-integration (Bierens \& Martins, 2010) and the number of relationships. The method uses trace and maximum eigenvalues to perform the test and Table 3 and Table 4 show the results of our survey.

Table 3

The results of trace

\begin{tabular}{|c|c|c|c|c|}
\hline Hypothotized No of CE(s) & Eigenvalue & Trace statistic & Critical Value (5\%) & Prob \\
\hline None * & 0.940729 & 108.9202 & 69.81889 & 0.0000 \\
\hline At most $1^{*}$ & 0.766715 & 52.40763 & 47.85613 & 0.0176 \\
\hline At most 2 & 0.478196 & 23.29773 & 29.79707 & 0.2317 \\
\hline
\end{tabular}

Table 4

The results of Eigenvalue

\begin{tabular}{lcccc}
\hline Hypothotized No of CE(s) & Eigenvalue & Max-Eigen Statistics & Critical Value (5\%) & Prob \\
\hline None * & 0.940729 & 56.51260 & 33.87687 & 0.0000 \\
At most 1* & 0.766715 & 29.10991 & 27.58434 & 0.0316 \\
At most 2 & 0.478196 & 13.00925 & 21.13162 & 0.4514
\end{tabular}

As we can observe from the results of Table 3 and Table 4, there are at most one CE for the proposed model of this paper. Now we can perform Vector Error Correction Model (VECM) to find the coefficients of the proposed model. Table 5 shows details of our findings,

\section{Table 5}

The results of the regression model

\begin{tabular}{lllllll}
\hline Variable & TE & TR & TL & TC & C & ECM(-1) \\
\hline Coefficient & -0.009119 & 0.514637 & -0.006029 & -0.39123 & 0.001244 & -0.653195 \\
t-student & $(4.86790)$ & $(-17.8872)$ & $(8.55360)$ & $(10.5613)$ & $(-3.98313)$ & $(-2.04378)$ \\
\hline
\end{tabular}

As we can observe from the results of Table 5, all t-student values are statistically meaningful and we can conclude that return of assets (ROA) is a function of other independent variables as follows,

$$
R O A=0.514 T R-0.009 T E-0.006 T L-0.391 T C+0.001
$$

In order to build a link between long term and short-term effects of variables we use ECM, which is equal to -0.653195 . This value shows that the effects of short term effects are discounted over the long term with a value of -0.653195 .

\subsection{The effects of external variables}

In this section, we repeat the same process for external variables. Fig. 2 shows response to Cholesky one S.D. Innovations. Again we have used Johansen and Juselius cointegration analysis to determine co-integration and the number of relationships and Table 6 and Table 7 show the results of our survey.

Table 6

The results of trace

\begin{tabular}{lcccc}
\hline Hypothotized No of CE(s) & Eigenvalue & Trace statistic & Critical Value (5\%) & Prob \\
\hline None * & 0.847446 & 99.69506 & 69.81889 & 0.0000 \\
At most 1* & 0.817870 & 63.97056 & 47.85613 & 0.0008 \\
At most 2* & 0.629038 & 31.61289 & 29.79707 & 0.0306 \\
At most 3 & 0.477597 & 12.77144 & 15.49471 & 0.1235 \\
\hline
\end{tabular}


Table 7

The results of Eigenvalue

\begin{tabular}{lcccc}
\hline Hypothotized No of CE(s) & Eigenvalue & Max-Eigen Statistics & Critical Value (5\%) & Prob \\
\hline None * & 0.847446 & 35.72449 & 33.87687 & 0.0298 \\
At most 1* & 0.817870 & 32.35767 & 27.58434 & 0.0112 \\
At most 2 & 0.629038 & 18.84145 & 21.13162 & 0.1015 \\
\hline
\end{tabular}

Response to Cholesky One S.D. Innovations \pm 2 S.E.
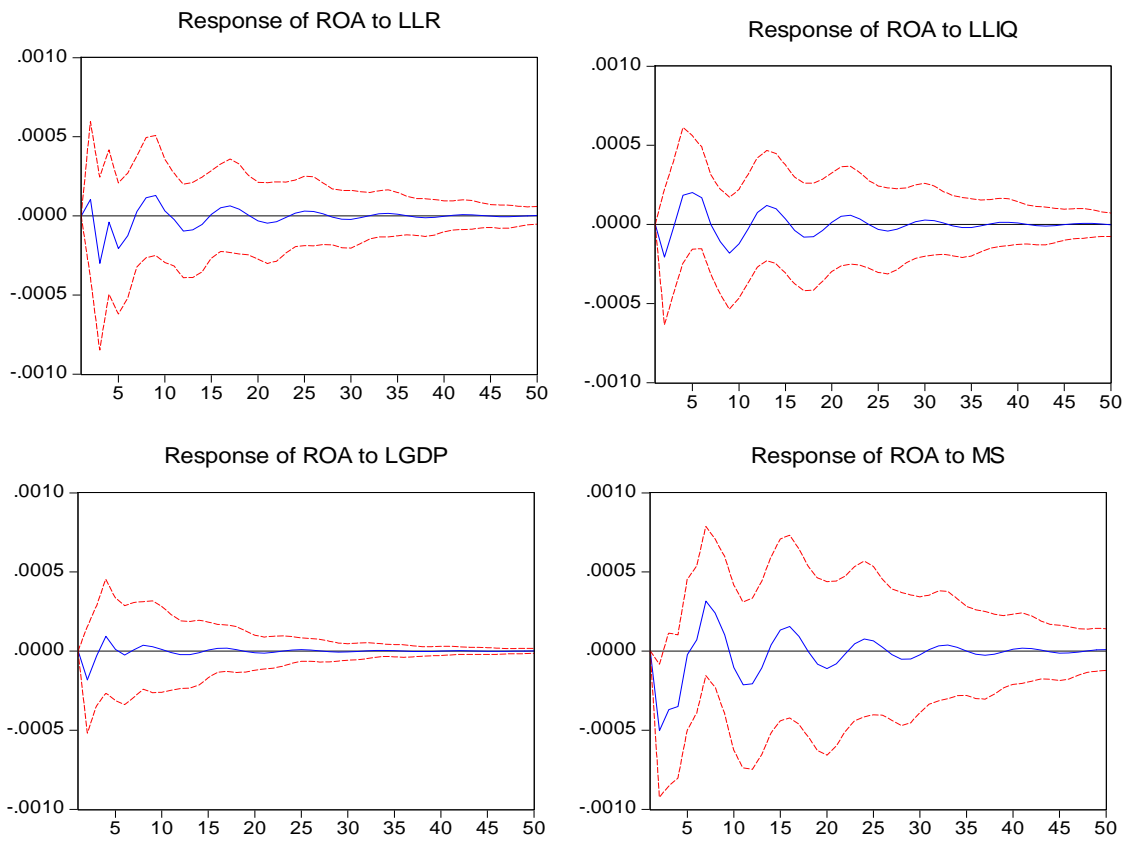

Fig. 2. Response to Cholesky One S.D. Innovations

Once the number of CE(s) becomes clear we can perform Vector Error Correction Model (VECM) to find the coefficients of the proposed model. Table 8 shows details of our findings,

\section{Table 8}

The results of the regression model

\begin{tabular}{lllllll}
\hline Variable & LLR & LLIQ & LGDP & MS & C & ECM(-1) \\
\hline Coefficient & -0.060667 & -0.103998 & 0.300519 & -0.266383 & -2.728964 & -0.052021 \\
t-student & $(-5.71020)$ & $(6.66645)$ & $(-7.66401)$ & $(2.71489)$ & $(-3.9831)$ & $(-2.03000)$ \\
\hline
\end{tabular}

As we can observe from the results of Table 8, all t-student values are statistically meaningful and we can conclude that return of assets (ROA) is a function of other independent variables as follows,

$$
R O A=0.061 \text { LLR }-0.104 L L I Q+0.301 L G D P-0.267 M S-2.729
$$

\subsection{The short and long term effects}

We now use the following model to consider short and long term relationships,

$R O A=F(L G D P, T R, M S, T C)$. 
Table 9 shows details of the necessary tests including Schwarz Information Criterion (SBC), Akaike Information Criterion (AIK), Logarithm of lag and Lag

Table 9

The results of SBC, AIK, Logarithm of lag and Lag

\begin{tabular}{cccc}
\hline LOGK & SBC & AIK & LAG \\
\hline 399.0126 & -37.35221 & -39.05384 & 0 \\
424.4318 & $-38.32324^{*}$ & -40.48987 & 1 \\
440.3584 & -38.29506 & $-41.03572^{*}$ & 2 \\
449.6781 & -37.5714 & -40.95238 & 3 \\
\hline
\end{tabular}

Impulse-Response Functions measure the effects of different inpulse of resuduals $\left(\varepsilon_{t}\right)$ on independent variables in different time horizons and the results of this function are shown in Fig. 3.

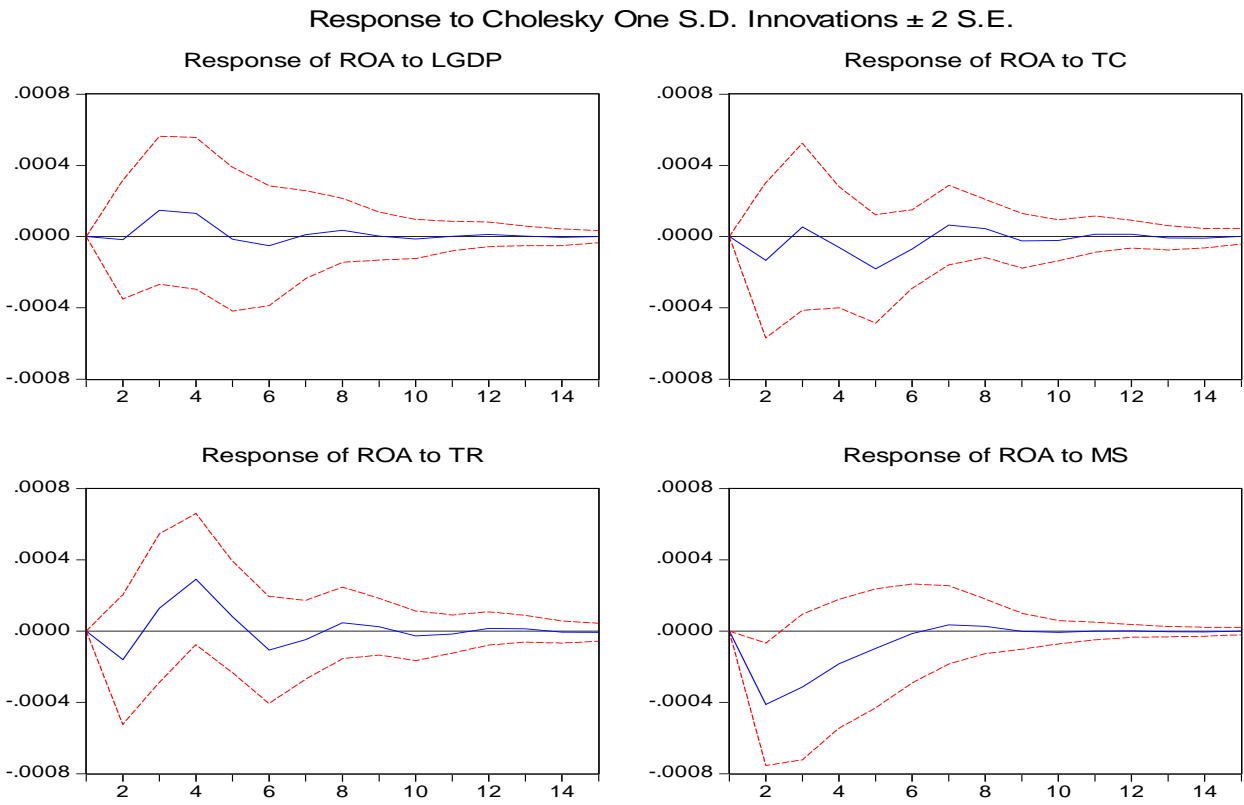

Fig. 3. Response to Cholesky One S.D. Innovations

Again we have used Johansen and Juselius cointegration analysis to determine co-integration and the number of relationships and Table 10 and Table 11 show the results of our survey.

Table 10

The results of trace

\begin{tabular}{lcccc}
\hline Hypothotized No of CE(s) & Eigenvalue & Trace statistic & Critical Value (5\%) & Prob \\
\hline None * & 0.880822 & 104.5683 & 76.97277 & 0.0001 \\
At most 1* & 0.799596 & 64.15262 & 54.07904 & 0.0049 \\
At most 2 & 0.566574 & 33.61166 & 35.19275 & 0.0733 \\
\hline
\end{tabular}

Table 11

The results of Eigenvalue

\begin{tabular}{lcccc}
\hline Hypothotized No of CE(s) & Eigenvalue & Max-Eigen Statistics & Critical Value (5\%) & Prob \\
\hline None * & 0.880822 & 40.41563 & 34.80587 & 0.0096 \\
At most 1* & 0.799596 & 30.54096 & 28.58808 & 0.0278 \\
At most 2 & 0.566574 & 15.88464 & 22.29962 & 0.3065 \\
\hline
\end{tabular}


Once the number of CE(s) becomes clear we can perform Vector Error Correction Model (VECM) to find the coefficients of the proposed model. Table 12 shows details of our findings,

Table 12

The results of the regression model

\begin{tabular}{lllllll}
\hline Variable & LGDP & TC & TR & MS & C & ECM(-1) \\
\hline Coefficient & 0.011656 & -0.82058 & 0.5173 & 0.025455 & -0.143907 & -0.586215 \\
t-student & $(-7.30761)$ & $(8.32174)$ & $(-9.43849)$ & $(-3.46711)$ & $(7.65970)$ & $(-1.66286)$ \\
\hline
\end{tabular}

As we can observe from the results of Table 12, all t-student values are statistically meaningful and we can conclude that return of assets (ROA) is a function of other independent variables as follows,

$$
R O A=0.012 L G D P+0.025 M S+0.517 T R-0.821 T C-0.144
$$

As we can observe, the results indicates that there is a positive and meaningful relationship between logarithm of growth domestic product and return on equities, which means as we expect one unit increase in LGDP, there is an increase of 0.012 on ROA. In addition, when the market share increase by one percent, there will be an increase $0.025 \%$ increase on ROA and an increase of one percent in the ratio of TR will yield to an increase of one percent in ROA.

\section{Conclusion}

In this paper, we have presented an empirical investigation to learn the effect of some internal and external factors on profitability in banking system. The proposed model of this paper has implemented three econometrics methods to study the behavior of internal, external and a combination of both factors on return on assets. the results indicates that there is a positive and meaningful relationship between logarithm of growth domestic product and return on equities, which means as we expect one unit increase in LGDP, there is an increase of 0.012 on ROA. In addition, when the market share increase by one percent, there will be an increase $0.025 \%$ increase on ROA and an increase of one percent in the ratio of TR will yield to an increase of one percent in ROA.

\section{Acknowledgment}

This paper is financially assissted by Bank Mellat and the authors would like to thank the officials for their support.

\section{References}

Ball, R., \& Shivakumar, L. (2008). Earnings quality at initial public offerings. Journal of Accounting and Economics, 45,324-349.

Bozec, Y., \& Laurin, C. (2008). Large shareholder entrenchment and performance: Empirical evidence from Canada. Journal of Finance \& Accounting, 35, 25-49.

Bierens, H.J., \& Martins, L. (2010). Time varying cointegration. Econometric Theory, 26, 14531490

Cain, A. C., Kolev, K., \& Mc Vay, S. (2009). A comprehensive analysis of the use of special items to manage earnings. Working Paper, Purdue University.

Khodaei Valahzaghard, M., Kashefi, M., Alikhani, A., \& Hosseini, S.E. (2012). The effect of macroeconomic factors on credit risk in the banking system of Iran. Management Science Letters, 2(5), 1747-1754.

Khodaei Valahzaghard, M., \& Salehi, A. (2012). Impact of the corporate governance characteristics and ownership on earnings quality of the Islamic private banks in Iran. Management Science Letters, 2(7), 2607-2614. 
Johansen, S. (1988). Statistical analysis of cointegrating vectors. Journal of Economic Dynamics and Control, 12, 231-254.

Johansen, S. (1991). Estimation and hypothesis testing of cointegrating vectors in Gaussian Vector autoregressive models. Econometrica, 59, 1551-1580.

Johansen, S. (1994). The role of the constant and linear terms in cointegration analysis of nonstationary variables. Econometric Reviews, 13(2).

Johansen, S., \& Juselius, K. (1990). Maximum likelihood estimation and inference on cointegration, with applications to the demand for money. Oxford Bulletin of Economics and Statistics, 52, 169210. 